\title{
Gene Delivery Technologies with Applications in Microalgal Genetic Engineering
}

\author{
Sergio Gutiérrez (D) and Kyle J. Lauersen *(D) \\ Biological and Environmental Sciences and Engineering Division, King Abdullah University of Science and \\ Technology (KAUST), Thuwal 23955-6900, Saudi Arabia; sergio.gutierrezzapata@kaust.edu.sa \\ * Correspondence: kyle.lauersen@kaust.edu.sa; Tel.: +966-(0)-12-808-2449
}

Citation: Gutiérrez, S.; Lauersen, K.J. Gene Delivery Technologies with Applications in Microalgal Genetic Engineering. Biology 2021, 10, 265 https://doi.org/10.3390/biology 10040265

Academic Editors: Michele Fabris and Raffaela Abbriano

Received: 31 January 2021

Accepted: 24 March 2021

Published: 26 March 2021

Publisher's Note: MDPI stays neutral with regard to jurisdictional claims in published maps and institutional affiliations.

Copyright: (c) 2021 by the authors. Licensee MDPI, Basel, Switzerland. This article is an open access article distributed under the terms and conditions of the Creative Commons Attribution (CC BY) license (https:/ / creativecommons.org/licenses/by/ $4.0 /)$.
Simple Summary: Microalgae and cyanobacteria are considered intriguing microbes for sustainable biotechnological production of a wide array of high-value metabolites from carbon dioxide and (sun)light. Mature genetic engineering concepts have only recently begun to emerge with the advent of customized DNA synthesis due to complicated genetics in these hosts. The delivery of heterologous DNA into cells is the first step in engineering concepts, yet is highly diverse in methodology, efficacy of expression cassette delivery, and applicability to variable organisms. This work overviews common and not-so common methodologies of DNA delivery, which may find use in engineering concepts for photosynthetic microbes.

Abstract: Microalgae and cyanobacteria are photosynthetic microbes that can be grown with the simple inputs of water, carbon dioxide, (sun)light, and trace elements. Their engineering holds the promise of tailored bio-molecule production using sustainable, environmentally friendly waste carbon inputs. Although algal engineering examples are beginning to show maturity, severe limitations remain in the transformation of multigene expression cassettes into model species and DNA delivery into non-model hosts. This review highlights common and emerging DNA delivery methods used for other organisms that may find future applications in algal engineering.

Keywords: microalgae; transformation; cyanobacteria; DNA

\section{Introduction}

Microalgae and cyanobacteria are interesting study organisms capable of photosynthetic growth on carbon dioxide $\left(\mathrm{CO}_{2}\right)$ as a sole carbon source. These organisms naturally synthesize different metabolites such as pigments, oils and lipids, sterols, starches, polysaccharides, and halogenated compounds, and algae are also amenable to contained, scalable growth in photobioreactors driven by (sun)light energy [1,2]. Genetic engineering of algae and cyanobacteria in the era of synthetic biology holds the promise of tailored production of novel and customized metabolites using sustainable waste $\mathrm{CO}_{2}$ as a feedstock. However, algae are a diverse and polyphyletic group of organisms which do not share close evolutionary relatedness and exhibit incredible variability in their genomes [3]. These features have hindered intensive molecular tool development except in a handful of model species, and their broader application to biotechnology has been slower compared to other hosts such as bacteria, yeast, plant, and mammalian cells $[2,4]$.

The genomic diversity of algae necessitates customized molecular tools that work with genetic architecture of a specific host. Once these tools are produced by piecemeal cloning or complete DNA synthesis, the reliable introduction of foreign genetic material into cells is an essential prerequisite to biotechnological concepts [5-7]. DNA delivery methods result in stable chromosomal integration or episomal/plasmid extrachromosomal replication of foreign transgene expression elements [7-9]. Methodologies of DNA delivery and cell membrane/wall permeabilization vary according to the host organism and target cellular 
compartment (organellar or nuclear). For example, cyanobacteria will natively take up DNA from their environment without the need for manipulation, while many eukaryotic algae maintain cell walls that necessitate more aggressive delivery methods [10,11].

Foreign DNA delivery can be achieved by mechanical agitation, surfactant permeabilization, electroporation, particle bombardment, and bacterial DNA transfer (conjugation or Agrobacterium tumefaciens-mediated) [9,12-15]. In addition to these classical methods, emerging techniques used in other cell systems that have not been widely applied to algae may potentially improve DNA delivery (Figure 1). Strategies based on cell penetrating peptides (CPP), polymers, metal-organic frameworks, nanoparticles, and liposomes have all been demonstrated in non-algal hosts [16-18]. This review examines recent progress in gene delivery methodologies and discusses their technical aspects, advantages, limitations, and potential in the context of algal biotechnology.
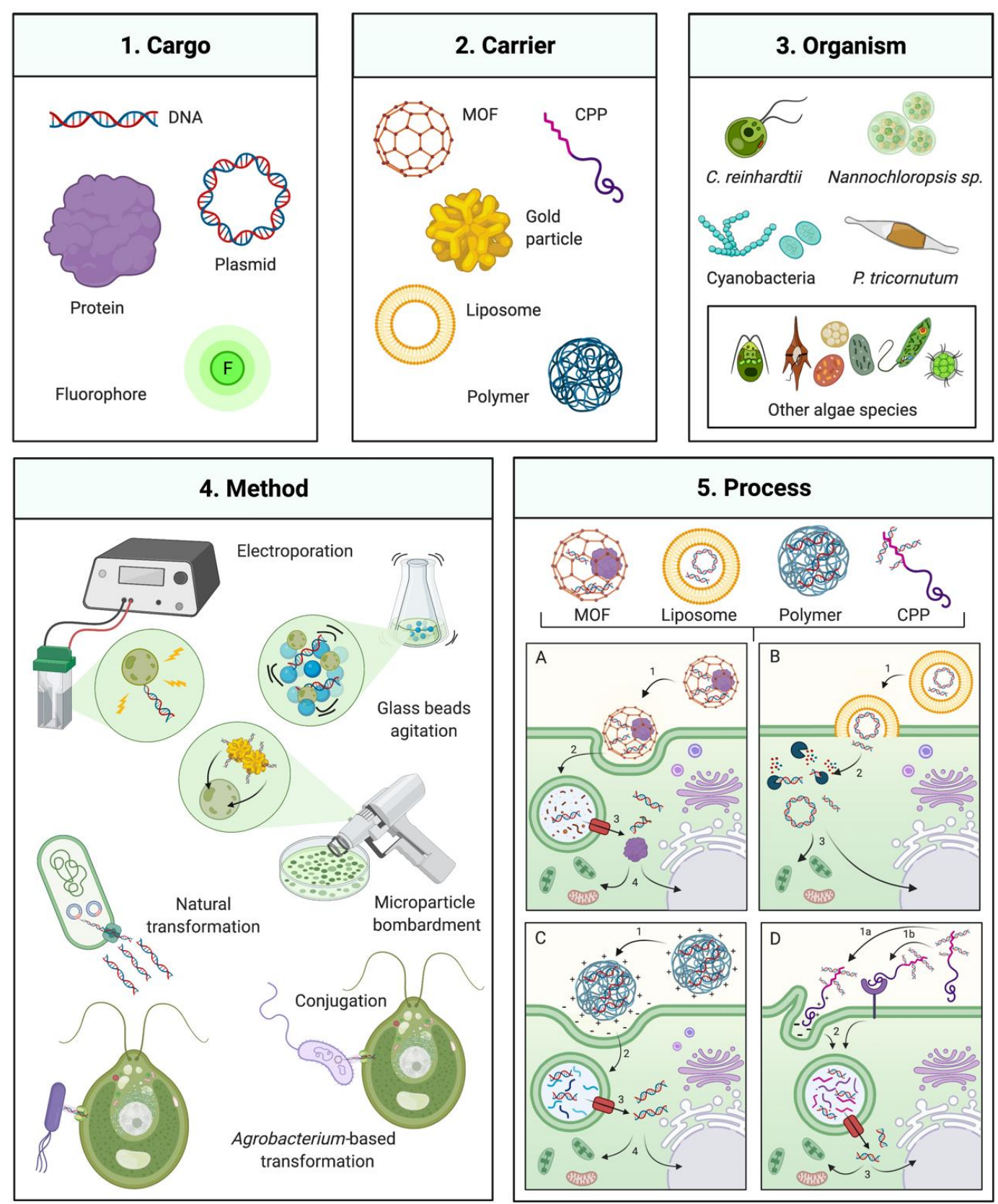

Figure 1. Gene delivery technologies for microalgae engineering. Overview of several available transformation technologies which have been or could be applied to algal engineering. (1) and (2) Several carriers that can mediate transformation of a 
DNA, protein, or chemical cargo (left panel) MOF: metal-organic framework, CPP: Cell-penetrating peptide. (3) Algal species which transformation has been commonly employed are depicted on the upper right: C. reinhardtii, Nannochloropsis sp., and P. tricornutum, including various cyanobacteria and other algal species as described in the manuscript. (4) Classical transformation methods are presented in the bottom left panel. (5) Process of transformation mediated by different DNA carriers and their interaction with the cell for delivery of the respective cargo. (5A) MOF-DNA, (5A1) recognition and cell uptake by endocytosis, (5A2) internalization and fusion with phagolysosome, 3 phagolysosome escape, 4 transport to nucleus, chloroplast or mitochondria; (5B) Liposome-DNA, (5B1) lyposome integration with cell membrane, (5B2) cargo (DNA or protein) exposed in cytoplasm and potential enzymatic degradation, 3 intact cargo transport to nucleus, mitochondria or chloroplast; (5C) Polymer-DNA, (5C1) cell recognition of polymer nanoparticle, charge interaction and cell uptake by endocytosis, (5C2) internalization and fusion with phagolysosome, (5C3) phagolysosome escape, (5C4) transport to nucleus, chloroplast or mitochondria; (5D) CPP-DNA, 1 cell recognition of CPP, by charge interaction (5D1a) or receptor recognition (5D1b) and cell uptake by endocytosis, (5D2) internalization and fusion with phagolysosome, (5D3) phagolysosome escape, (5D4) Transport to nucleus, chloroplast or mitochondria. Created with BioRender.com.

\section{Traditional Algal Transformation Techniques}

\subsection{Agitation of Cells in the Presence of DNA and Non-Ionic Surfactants}

The agitation of algal cells in the presence of glass beads, polyethylene glycol (PEG), and foreign DNA has become a standard protocol for the delivery of foreign DNA into the model green microalgae C. reinhardtii and other species as Cyanidioschyzon merolae, Chlorella vulgaris, and Dunaliella salina [14,19-21]. This protocol has been adopted for nuclear and chloroplast transformation and can be applied to cell wall deficient cell lines or those with a cell wall when chemo/enzymatic removal is performed before transformation (as with Chlorella strains) [13-15,22-24]. Agitation-based transformation is achieved by agitation (vortexing) of cells in the presence of a physical agitator (glass beads), a non-ionic surfactant (i.e., polyethylene glycol (PEG)), and DNA [14,25]. Transformation efficiency depends on many factors such as cell size, presence or absence of a cell wall, duration of agitation, velocity, the concentration of surfactant, and the use of linear or circular DNA [26]. The frequency of DNA integration into the $C$. reinhardtii genome with glass bead agitation has been reported at $\sim 10^{3}$ transformants $\mu \mathrm{g}$ of $\mathrm{DNA}^{-1}$ with $\sim 10^{8}$ cells $\mathrm{mL}^{-1}$ starting cell concentration [14]. Reports have shown that numerous other non-reactive materials, such as silicon carbide whiskers can also serve this purpose [27]. Agitation-based transformation protocols are advantageous as they do not require specialized equipment, and are inexpensive and relatively fast $[14,15]$.

A significant limitation of the technique is the requirement of cell wall removal, which can be achieved with the autolysin protein of $C$. reinhardtii for itself, or other enzyme cocktails (e.g., cellulase, macerase, pectinase, and hemicellulose) for other hosts [14,19,28-32]. Reports have shown that cell-wall free protoplasts of Chlorella ellipsoidea and the naturally cell wall deficient $C$. merolae have been transformed using DNA and PEG without mechanical agitation, suggesting that surfactant mediated permeabilization is sufficient to enable DNA uptake [33]. However, the main drawback of agitation-based transformation techniques is the low transformation efficiency [34]. This has led to development of other more efficient strategies.

\subsection{Electroporation}

DNA transformation by electroporation is as an alternative method in numerous algae and pioneered in C. reinhardtii [34]. This technique uses electrodes to generate voltage differential across the cell membrane, temporarily disturbing the phospholipid bilayer, allowing molecules to pass into the cell [35,36]. Transformation efficiencies from electroporation vary according to factors such as field-strength, pulse length, ionic strength of medium composition, temperature, cell membrane characteristics, the species used, its molecular toolkit, and the presence of cell-wall [36,37]. Electroporation can increase transformation efficiency up to 100-fold over agitation and is not affected by the cell wall. Fewer sequence deletions have been observed at the genomic insertion sites than those seen from agitation transformation $[34,37,38]$. Electroporation has been shown to enable 
the transformation of cell-wall containing algae and cyanobacteria such as Monoraphidium neglectum, Nannochloropsis sp., Phaeodactylum tricornutum, C. reinhardtii, Anabaena, and Nostoc punctiforme [34,35,39-44]. Electroporation is a useful technique for delivering DNA, RNA, proteins, nucleotides, and dyes into cells $[34,35,45]$. Electroporation is a rapid protocol and requires equipment which is often present in microbial laboratories to transform bacterial cells $[37,46]$.

Electroporation efficiencies were increased by considering the specific mitotic phase of $C$. reinhardtii growth [47]. Synchronization of $C$. reinhardtii cultures has been shown to increase transformation efficiency after three days. C. reinhardtii culture synchronization using $28^{\circ} \mathrm{C}$ during the light phase and $18^{\circ} \mathrm{C}$ in the dark phase was also shown to enable increased homologous recombination efficiencies specifically at 12 hours after illumination initiation [48]. Digital microfluidics (DME) have also been used to optimize electroporation protocols, using a fluid mixture of cell/DNA droplets encapsulated in biocompatible oil, and electric pulses applied from an array of microelectrodes to the droplets [49,50]. DME showed an efficiency of $2.5 \times 10^{4}$ of $C$. reinhardtii mutants per $\mu \mathrm{g}$ of DNA without cell wall removal with an initial concentration of $2 \times 10^{6}$ cells $\mathrm{mL}^{-1}$ algal cells, and $1 \mu \mathrm{g}$ DNA [49]. A square-electric-pulse electroporation technique has also been reported with efficiencies of $6 \times 10^{3}$ C. reinhardtii transformants per $\mu \mathrm{g}$ of DNA with $1.5 \times 10^{7}$ cells $\mathrm{mL}^{-1}$ initial cell density $0.1 \mu \mathrm{g}$ of DNA [47]. However, this technique has not been broadly adopted, as it requires specialized equipment. It was described in N. limnetica, which contains a rigid cell wall, that treatment with $10 \mathrm{mM}$ lithium acetate and $3 \mathrm{mM}$ dithiothreitol (DTT) before electroporation improved transformation efficiency by increasing cell wall permeability, resulting in $1.1 \times 10^{7}$ transformants per $\mu$ g of DNA with an initial concentration of $3.3 \times 10^{9}$ cells $\mathrm{mL}^{-1}$ and $4 \mu \mathrm{g}$ of DNA [40].

\subsection{Microparticle Bombardment}

Microparticle bombardment is one of the most versatile gene delivery methods due to its ability to transform the nucleus, mitochondria, or chloroplast genomes and even transform cells containing cell walls [13,51-53]. Microparticle bombardment is based on accelerated non-reactive metal (gold or tungsten) micro-projectiles coated with DNA being shot at and colliding with target cells $[1,51]$. The impact of these particles allows them to penetrate the cells and deliver foreign DNA. Transformation efficiency depends on the starting cell density, target organelle, selection efficiency, the number of DNA-coated particles, the DNA concentration on each particle, the kinetic energy of the particles, temperature, and ability of the cell to regenerate after particle damage [54].

The most common use for this technique is the transformation of chloroplast genomes, as it enables penetration of DNA through multiple membrane layers, but it has also recently been used to transform circular plasmids into the nucleus of the red alga Porphyridium purpureum $[23,51,55]$. Unlike agitation, but similar to electroporation, cell-wall presence does not affect transformation efficiency; however, cell viability can be disturbed if many micro-projectiles are used $[51,56]$. The efficiency of nuclear transformation in C. reinhardtii has been as low as 15 transformants per $\mu \mathrm{g}$ of DNA, with $\sim 10^{7}$ cells $\mathrm{mL}^{-1}$ starting cell concentration and $0.8 \mu \mathrm{g}$ of DNA [13]. Efficiencies reported in D. salina, Volvox carteri and P. tricornutum are $2.5 \times 10^{-5}, 1.7 \times 10^{2}$, and $1.0 \times 10^{2}$ transformants per $\mu \mathrm{g}$ of DNA (0.1-0.7 $\mu$ g of DNA), respectively, with $10^{5}-10^{7}$ cells $\mathrm{mL}^{-1}$ as starting cell density [57-59]. However, it was reported that in $C$. reinhardtii, transformation efficiency could be improved when smaller particles are used $(0.6 \mu \mathrm{m}$ vs. $1.0 \mu \mathrm{m})$ [60].

Microparticle bombardment has also been described for the delivery of 24-68 kDa proteins, a technique called proteolistics. This approach is a simple physical deposition of target protein onto delivery substrate which is then used as other microprojectiles [61]. The application was shown to deliver Cas9-gRNA ribonucleoprotein (RNP) into P. tricornutum, where knock out of the PtUMPS and PtAPT genes led to 5-fluoroorotic acid (5-FOA) and 2-fluoroadenine (2-FA) resistance at an efficiency of $\sim 10^{-6}$ per $10^{6}$ cells $\mathrm{mL}^{-1}$ [62]. This 
technique was also found to be suitable for multiplexing mutations [62] and could become a powerful strategy for generating targeted knockouts in this and other diatoms/algae.

One disadvantage of bombardment is the requirement of gene-gun infrastructure as well as reagents and equipment. Transformation parameters must also be optimized for every alga and target cell compartment/genome $[9,63]$. One thing that must be considered is the potential post-transcriptional gene silencing (PTGS) due to the relatively high copy number of transgenes integrated into the genome [53,64].

\section{Natural Transformation, Bacterial Conjugation, and Agrobacterium-Mediated Transformation}

\subsection{Natural Transformation}

The natural uptake of DNA from the surrounding environment without surfactants is a process found in cyanobacteria species $[65,66]$. This natural transformation capacity was exploited in 1970 as a simple tool for cyanobacterial genetic engineering [67]. Biotechnologically relevant species such as Synechocystis PCC 7942, Synechococcus PCC 7002, and Thermosynechococcus elongatus BP-1 are naturally transformable [65,67-69]. However, the detailed mechanism of natural transformation remains unclear, although pili type IV and secretion system type II have been shown to play roles in this process [70-73]. Natural transformation functions together with replicative and integrative plasmids, which differ only in their homologous recombination regions or replicative elements. Transformation efficiency relies on cyanobacterial physical and chemical features (e.g., polysaccharides), culture state (i.e., mid-exponential growth), and the use of DNase inhibitors (i.e., EDTA) [74,75]. Foreign DNA characteristics such as concentration, length, and single or double-stranded state play a role in the number of transformants obtained [66,76,77]. Natural transformation provides the most practical and straightforward method for transformation; however, it is limited to species in which this a native feature [74].

\subsection{Bacterial Conjugation}

Conjugation is based on the ability of bacteria to share genetic information by exchanging plasmids through pili. This natural process can be employed using either a double or triple vector approach combining shuttle, conjugative, and helper plasmids. The shuttle and helper plasmids mediate the transfer of a conjugative plasmid between $E$. coli and the target host while the helper plasmid aids transformation by preventing vector degradation by endogenous restriction systems; it codes for DNA methylases (Aval, AvaW, and AvaIII) that prevent target host restriction enzyme recognition $[78,79]$. The helper vector contains an oriT-region, bom-site, and mob genes that encode a nickase and enable conjugation $[80,81]$. Bacterial conjugation has been used commonly in cyanobacterial species such as Synechococcus, Prochlorococcus, N. punctiforme, Anabaena, and Synechocystis sp. and recently in eukaryotic algae such as P. tricornutum, Thalassiosira pseudonana, Acutodesmus obliquus, and Neochloris oleoabundans [79,81-88]. The effectiveness of transformation by conjugation is based on the capability of the algal recipient strain to integrate and maintain the vector, either in the chromosome, in endogenous plasmids, or as an episomal plasmid $[78,79,87,88]$.

Episomes, circular plasmids which self-replicate and do not integrate into the chromosome, can be efficient and straightforward vectors to enable transgene delivery of desired genetic elements between bacteria, cyanobacteria, and eukaryotes. Episomes avoid insertions and knock-out of non-targets and replicate independently from chromosomes [89-91]. Yeast centromere sequences (CEN/ARS) were found to act as autosomal replicating elements that allow stable maintenance of the circular episomal plasmid in diatoms [79,92]. Factors such as the growth phase of both target and donor organisms are crucial factors for proper conjugation [93]. Episomal vectors to transform microalgae via conjugation provide an efficient means of multi-gene pathway transfer due to stable self-replication of episomal vector and minimal possibility of positional or epigenetic effects [79]. Conjugation has the advantage over electroporation, microparticle bombardment, and glass-beads agitation 
to deliver larger DNA fragments [45]. The use of the conjugation-based method in $P$. tricornutum, N. oceanica, and Neochloris oleoabundans has been demonstrated to generate mutants with higher transformation efficiency compared to microparticle bombardment transformation: $500-1000$ transformants $/ 10^{8}$ cells $/ 200$ ng DNA (conjugation) compared to 5-25 transformants $/ 10^{8}$ cells $/ 2.5 \mu \mathrm{g}$ DNA (bombardment) in P. tricornutum $[87,94-96]$.

\subsection{Agrobacterium-Mediated Transformation}

The use of A. tumefaciens to transform plant cells relies on the natural infection process of the bacterium, which causes crown gall tumors on various plant species [97]. Natural tumor formation is a consequence of replicating a single-stranded copy of the transferred bacterial tumor-inducing (Ti) plasmid. The Ti plasmid and A. tumefaciens have been exploited since 1988 when it was found to allow transfer and permit stable integration of DNA fragments into a target higher plant genomes and has even been shown to transform mammalian cells [98-100]. The technique has the reported advantage of low gene rearrangements and foreign transcript silencing in plant cell lines [101,102].

A. tumefaciens-based transformation of algae has been reported in several species, although its use has not been wildly adopted. Reports exist of transformation by Agrobacterium method in C. reinhardtii, H. lacustris, Chlorella sp., Dunaliella bardawil, Symbiodinium sp., Nannochloropsis sp. and Parachlorella kessleri [98,103-107]. However, questions remain about how the bacterium, which evolved to infect plant cells, can infect evolutionarily distant algae and whether the infection requires specific recognition machinery on the target, or whether it is target independent. The standard protocol for Agrobacterium-mediated transformation is to mix target cell cultures with Agrobacterium containing a transgene cassette of interest; the mixture is exposed with the virulence agent acetosyringone, which signals the bacterium to infect wounded plant tissue. After transformation of the target cell by the bacterium, the selection is made using an antibiotic that can be selective against the bacterium while selecting the transformed cells. Variable transformation efficiencies have been reported depending on the protocol followed [103,108-110]. Factors such as temperature, $\mathrm{pH}$, and time of virulence gene induction have been reported to have a substantial effect on transformation efficiency [111]. This method may enable integrating multigene pathways into host genomes as the capacity of the Ti plasmid has been reported as large as $150 \mathrm{kbp}$. If stably integrated into the genome, this would vastly outperform current methods of gene delivery that exhibit random nuclease digest en route to the nucleus, especially in green algae [112-114]. However, a recent report indicated that this method is no better than electroporation for stable integration of a plasmid containing a luciferase expression cassette and a selectable marker cassette into Parachlorella kessleri [103]. Further investigation is required to determine if this standard plant transformation protocol can be robustly applied to enhancing multi-gene expression cassette delivery to algal hosts.

\section{Non-Traditional and Emerging Transformation Technologies}

\subsection{Cell-Penetrating Peptides}

Protein vehicles for DNA transformation hold promise for enhancing transformation efforts in algae. Owing to non-covalent interactions with DNA structures, protein molecules can assist in the penetration of nucleic acids into cells and affect their integration into the genome [115]. Small delivery peptides, known as cell-penetrating peptides (CPP), have been the most commonly used among different cell-penetrating compounds. CPPs are small peptides ( $<30$ amino acids) that can mediate the penetration of protein-cargo complexes into cells [116]. CPPs have been found from many different origins as some are derived from translocation peptide signals, and others are chimeric peptides with combined or engineered domains $[117,118]$.

CPPs can be categorized as amphipathic, cationic, and hydrophobic, based on their physical chemistries and interaction patterns with cellular structures. Amphipathic CPPs have both hydrophobic and hydrophilic characteristics. Their amphipathic properties arise primarily from $\alpha$-helical structures of both polar and non-polar amino acid regions, 
which are involved in their intracellular transport and preferential accumulation in the nucleus [119]. Common amphipathic peptide examples include modified poly-lacticco-glycolic acid (MPG) peptide, transportan, tumor suppressor peptide (ARF), model amphipathic peptide (MAP), and vascular epithelial cadherin (pVEC), which have all been used to mediate cellular uptake of various substrates in cell-culture [120-122]. MPG has been found to have a relatively high affinity for single and double-stranded DNA as well as rapid $(<1 \mathrm{~h})$ and efficient $(90 \%)$ delivery of fluorescent oligonucleotides into the nucleus of human fibroblast cells [120]. MAP was developed to provide a non-endocytic translocation vehicle into endothelial cells [122]. MAP is taken up by cells directly by several mechanisms: inverted micelle, pore formation, and membrane thinning [123]. Another CPP, pVEC, was used to study internalization patterns in plant epidermal and leaf cells. Cellular uptake of fluorescently labeled pVEC in plant cells was concentration and inversely temperature-dependent [121].

Cationic CPPs are peptides that contain a continuous chain of basic amino acids in their domains. Common cationic motifs are oligo-arginines, leucine-zipper, and paired tryptophan peptides. Cationic motifs act as CPPs due to their strong electrostatic binding and transient permeabilization of the cell membrane [124,125]. The transactivating transcription protein (Tat) and penetratin are two commonly employed cationic CPPs $[126,127]$. Tat has been used to demonstrate the importance of cationic motifs in CPP internalization and nuclear translocation using embryonic rat brain cell cultures [127]. Hydrophobic CPPs contain non-polar amino acids in their motifs with a high affinity for hydrophobic zones of the cell membrane [124]. However, hydrophobic CPPs have rarely been reported, and only for $G$ protein-coupled receptor delivery, due to the complicated chemical strategies needed for their production [128].

It has been shown that CPP-mediated delivery systems do not have a cytotoxic effect in cyanobacteria. In Synechocystis sp. PCC 6803, the Tat peptide, coupled with the green fluorescence protein (GFP), was efficiently internalized by endocytosis [129]. The internalization rate may differ according to the cell type (yeast, mammalian, algae, or plant). CPPs have a predisposition to move to the nucleus after being internalized in mammalian cells, a tendency that might also be true for other eukaryotes such as algae [129-131]. This property necessitates viability assays for each target cell type [121,130,132,133]. Similar to other transformation methods, the presence of a cell wall is an issue for effective CPP-DNA delivery. A CPP-dsDNA complex was able to penetrate $D$. salina, which is naturally cell wall-deficient, but not into P. tricornutum or cell wall containing C. reinhardtii $[130,132]$.

CPPs have been applied in Drosophila antennapedia, Saccharomyces cerevisiae, Candida albicans, human lymphocytes cells, and the cyanobacteria Synechocystis sp., S. elongatus, as well as the eukaryotic algae D. salina, P. tricornutum, Chlorella vulgaris, and C. reinhardtii. In these systems, translocation of fluorescent proteins, phosphatases, dsDNA, and dsRNA into the cells was shown $[126,129,130,132-136]$. Diverse CPPs have been used in C. reinhardtii to deliver fluorochrome conjugates. It was noted through flow cytometry and confocal microscopy that Tat, $\mathrm{pVEC}$, penetretrin, and transportan exhibit variable performance in cargo delivery. In a cell wall containin C. reinhardtii strain, pVEC seems to have the highest efficiency with uptake at $10 \mu \mathrm{M}$ in $15 \mathrm{~min}$, similar to S. cerevisiae and C. albicans $[134,135]$. pVEC has also been recently demonstrated to enable ribonucleoprotein (RNP) delivery to $C$. reinhardtii with or without cell walls to knock out Maa7 and FKB12 genes [137]. The delivery is based on the hydrophobic region of PVEC which interacts with the external side of a cell wall and further translocates the CPP and cargo across the lipid bilayer $[137,138]$. However, no study has yet reported gene expression construct delivery into algal cells mediated by CPPs.

\subsection{Cell-Penetrating Polymers}

Beyond the surfactant properties of PEG, polymers such as polyethyleneimine (PEI), polyethylene acrylic acid (PEAA), and polyamidoamine (PAMAM) have also been shown to mediate DNA delivery in the absence of exogenous endosomolytic agents to various 
cell types [139,140]. These polymers have been used successfully to transform mammalian cells and have been extensively studied because of their efficient endo-lysosome escape properties [141,142]. Polymer acetylation, the addition of permethyl, perethyl, choline, and long-chain alkyl groups have increased gene delivery efficiency up to 26-fold [143,144]. The advantages of polymer encapsulation of DNA are efficient protection from degradation and the possibility of polymer chemical functionalization to improve the target specificity [145]. Polymers represent a promising DNA delivery alternative in algal biotechnology due to their excellent encapsulation capability and demonstrated stabilizing properties. However, further development of polymer chemistries is needed. There are currently no reports of polymer mediated DNA transformation to algal cells and the issue of cell wall interference observed for other strategies will likely also be a hindrance to their broader application.

\subsection{Metal-Organic Frameworks}

Metal-organic frameworks (MOFs) are protein-based nanostructures that contain metal ions linked together by organic bridging ligands to form reticular structures that can also be used to assist DNA and other cargo delivery into cells. MOFs have extraordinarily high surface areas, tunable pore size, low densities, and adjustable internal surface properties [146-148]. Nucleic acids can be encapsulated into peptide-inorganic nanoparticles with dimensions of 4.0-7.8 nm, and ion metals of the structures allow the hybrid carriers to be transported to the nucleus [148-151]. Aminoclay is a MOF which has been used to effectively deliver DNA, polysaccharides, enzymes, and proteins into mammalian, plant, and $C$. reinhardtii cells [152-157]. Aminoclay was used for transformation of the hygromycin-B 4-O-kinase (hygromycin-B resistance gene $h p h$ ) into cell-wall containing C. reinhardtii, and the nanoparticle-DNA complex was found to enable the transformation efficiency of 503 mutants with a starting cell density of $4 \times 10^{6}$ cells $\mathrm{mL}^{-1} ; 500 \mu \mathrm{L}$ of the cell culture and $500 \mu \mathrm{L}$ of the aminoclay-DNA (i.e., DNA $=150 \mathrm{ng} / \mu \mathrm{L}$; aminoclay $=100 \mathrm{mg} / \mathrm{L}$ ) mixture solution were used for transformation [152].

A MOF subclass formed by coupling zinc cations $\left(\mathrm{Zn}^{+2}\right)$ with methylimidazole (ZIF-8) has been effective for delivering macromolecules, including DNA, proteins, carbohydrates, and fluorescent compounds, as well as Cas9 nuclease and single-guide RNA (sgRNA) into Chinese hamster ovary (CHO) cells [147,158-162]. The ZIF-8 MOF showed a loading efficiency of $17 \%$ of sgRNA-Cas 9 nuclease and enhanced endosomal escape by the protonation of the ZIF-8 imidazole ring release of the cargo into the cytoplasm [147]. The ZIF-8 structure can also be modified with a coating of cell membrane derivates to improve cell-type targetability, suggesting this could also be done to facilitate alga-specific chemistries [148]. MOFs exhibit unique properties such as biocompatibility, aqueous stability, excellent $\mathrm{pH}$-buffering capacity, and exceptional versatility and could be further explored for gene delivery into algal systems.

\subsection{Liposome-Mediated Transformation}

Liposome-mediated transformation is a convenient method for delivering biomolecules (proteins and nucleic acids) into mammalian, bacterial, yeast, and plant protoplast cells [163-166]. Liposomes are microscopic phospholipid cationic or neutrally charged vesicles made of a concentric single lipid bilayer. Within the vesicle, cargo to be transformed can be loaded in the central aqueous compartment, including nucleotides or proteins. Liposomes have a cationic structure that facilitates nucleic acid encapsulation; they are usually composed of 1,2-dioleoyl-3-trimethylammonium propane (DOPA) or dieleoylphosphatidylethanolamine (DOPE) and coated with 1,2-distearoyl-sn-glycero-3phosphoethanolamine-N-[polyethylene glycol] (PEG2000-DSPE) [167,168]. Liposomes are formed based on amphipathic phospholipid characteristics that are self-assembled in aqueous media into a bilayered structures. Inside the bilayer, polar groups line up to create a water-attracting surface while their lipophilic chains face each other to yield a waterfree zone. Under certain conditions (e.g., shaking or heating), the phospholipid bilayers continuously enclose the dispersing aqueous medium and form a vesicular system. This 
structure enables encapsulation of hydrophilic and hydrophobic materials inside the inner aqueous core and the lipid bilayers, respectively. Liposome-encapsulation generates a stable complex, protecting genetic cargo from degradation outside of the cell [169]. Liposome complexes fuse with the negatively charged cell membranes and merge into cells, releasing the internal cargo [164]. These structures are interesting emerging tools for transforming multiple plasmids because they form a protective layer against enzymatic degradation outside of the cell [170]. However, lipid composition, liposome preparation, membrane bilayers (lamellarity), and sizes have to be optimized for appropriate efficiency [170-172]. Transformation with liposomes requires protoplasts or cell-wall deficient lines, and cargo is not protected from enzymatic digestion inside the cells upon liposome release, which is the main drawback of this technique [170]. Thus far, there are no reports of the liposomemediated transformation of algae. However, liposomes should be useful in transforming cell-wall deficient algae strains of $C$. reinhardtii, D. salina, and C. merolae or protoplasts made from cell-wall containing species.

\section{Considerations for the Future of Algal Transformation}

The choice of the transformation method substantially impacts the overall effectiveness of an engineering strategy for a target host as this step enables the transfer of heterologous DNA into a target organism/cell line. Highlighted in this work are some transformation techniques for DNA and protein complexes that have either not yet been applied or have only recently been tested in algae, including cell-penetrating peptides, polymers, liposomes, and metal-organic-frameworks. These techniques may open new avenues of efficiency for protected DNA construct delivery to algal genomes. Whichever method is chosen for a target alga, it is essential to consider infrastructure requirements, the availability of molecular tools, expression efficiency, and reproducibility. Some of these factors are compared in Table 1. Considerations such as nuclear or organellar genome target, chromosomal/plasmid integration or episomal expression, and desired transgene copy number play a role in deciding which transformation technique to use.

Although many examples exist, it is clear that there is no one-size-fits-all transformation strategy as each host organism has its own set of circumstances, especially related to availability of molecular tools and the presence/absence of a cell wall. Techniques such as bacterial conjugation and Agrobacterium-mediated transformation have some reported success in algal strains $[103,104,106-109]$. Conjugation has shown promise for transfer circular self-replicating episomal plasmids into diatoms and chromosomal integration in some microalgal species $[79,87,92]$. The major limitation in most algal systems is delivering multiple sets of transgenes in one transformation round. It remains to be seen if the non-traditional transformation techniques discussed above can help enable the stable transformation of larger DNA fragments containing multigene pathways in single transformation steps. This is especially important to reduce degradation/rearrangements and promote other avenues of genome manipulation in green algal species. 
Table 1. Advantages and disadvantages of transformation strategies and reported efficiencies in algae and cyanobacteria.

\begin{tabular}{|c|c|c|c|c|c|c|c|}
\hline Method & Species & Advantage & Disadvantage & 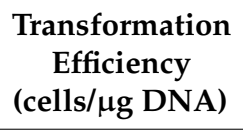 & $\begin{array}{c}\text { Initial Cell } \\
\text { Concentration } \\
(\text { cells/mL) }\end{array}$ & $\begin{array}{c}\text { DNA } \\
\text { Added }(\mu \mathrm{g})\end{array}$ & Ref. \\
\hline $\begin{array}{c}\text { Glass bead } \\
\text { agitation and PEG } \\
\text { mediated DNA } \\
\text { delivery }\end{array}$ & $\begin{array}{l}\text { C. reinhardtii } \\
\text { C. merolae } \\
\text { C. vulgaris } \\
\text { C. ellipsoidea } \\
\text { D. salina } \\
\text { protoplasts }\end{array}$ & Simple; inexpensive; fast & $\begin{array}{l}\text { Requires cell wall } \\
\text { removal/deficiency; } \\
\text { occasional genome } \\
\text { lesions }\end{array}$ & $10^{3}$ & $10^{8}$ & 2 & {$[14,15]$} \\
\hline Electroporation & $\begin{array}{l}\text { C. reinhardtii } \\
\text { M. neglectum } \\
\text { Nannochloropsis sp. } \\
\text { P. tricornutum } \\
\text { Anabaena sp. } \\
\text { N. punctiforme } \\
\text { N. limnetica }\end{array}$ & $\begin{array}{l}\text { Not affected by cell wall } \\
\text { presence; Occasional } \\
\text { genome } \\
\text { lesions }\end{array}$ & $\begin{array}{l}\text { Specialized } \\
\text { equipment }\end{array}$ & $10^{5}$ & $10^{8}$ & 2.5 & {$[34,37,46,48]$} \\
\hline $\begin{array}{l}\text { Digital microfluidic } \\
\text { electroporation (DME) }\end{array}$ & C. reinhardtii & $\begin{array}{c}\text { Not affected by cell wall } \\
\text { presence; occasional genome } \\
\text { lesions }\end{array}$ & $\begin{array}{l}\text { Specialized } \\
\text { equipment }\end{array}$ & $10^{4}$ & $10^{6}$ & 1 & [49] \\
\hline $\begin{array}{l}\text { Square electric pulse } \\
\text { electroporation }\end{array}$ & C. reinhardtii & $\begin{array}{c}\text { Not affected by cell wall } \\
\text { presence; occasional genome } \\
\text { lesions }\end{array}$ & $\begin{array}{l}\text { Specialized } \\
\text { equipment }\end{array}$ & $10^{3}$ & $10^{7}$ & 0.1 & [47] \\
\hline $\begin{array}{c}\text { Microparticle } \\
\text { bombardment (gene gun) }\end{array}$ & $\begin{array}{l}\text { C. reinhardtii } \\
\text { P. purpureum } \\
\text { D. salina } \\
\text { V. carteri } \\
\text { P. tricornutum }\end{array}$ & $\begin{array}{l}\text { Plastid target; not affected by } \\
\text { cell wall }\end{array}$ & $\begin{array}{l}\text { Cell viability } \\
\text { compromise; } \\
\text { specialized } \\
\text { equipment }\end{array}$ & $10^{2}$ & $10^{5}$ & 0.1 & {$[23,51-53,59]$} \\
\hline Natural transformation & $\begin{array}{l}\text { Anacystis nidulans } \\
\text { Synechocystis sp. } \\
\text { Synechococcus sp. } \\
\text { T. elongatus }\end{array}$ & $\begin{array}{l}\text { Straightforward method for } \\
\text { extensive genetic } \\
\text { engineering }\end{array}$ & $\begin{array}{l}\text { Limited to some } \\
\text { species }\end{array}$ & $10^{4}$ & $10^{7}$ & 5 & {$[67,68,75]$} \\
\hline
\end{tabular}


Table 1. Cont.

\begin{tabular}{|c|c|c|c|c|c|c|c|}
\hline Method & Species & Advantage & Disadvantage & 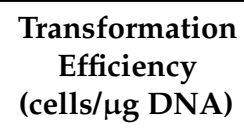 & $\begin{array}{l}\text { Initial Cell } \\
\text { Concentration } \\
(\text { cells } / \mathrm{mL})\end{array}$ & $\begin{array}{c}\text { DNA } \\
\text { Added }(\mu \mathrm{g})\end{array}$ & Ref. \\
\hline Bacterial conjugation & $\begin{array}{c}\text { Anabaena } \\
\text { Nostoc sp. } \\
\text { Prochlorococcus sp. } \\
\text { Synechococcus sp. } \\
\text { Synechocystis sp. } \\
\text { N. punctiforme } \\
\text { P. tricornutum } \\
\text { T. pseudonana } \\
\text { A. obliquus } \\
\text { N. oleoabundans } \\
\text { N. oceanica }\end{array}$ & $\begin{array}{l}\text { Low non-target } \\
\text { insertions/knockouts; } \\
\text { independent episome } \\
\text { replication; allows delivery } \\
\text { of large DNA fragments }\end{array}$ & $\begin{array}{l}\text { Relies on target species } \\
\text { characteristics based on } \\
\text { recipient capability to } \\
\text { integrate or maintain the } \\
\text { vector }\end{array}$ & $10^{4}-10^{6}$ & $10^{7}-10^{9}$ & $30-50$ & {$[81,82,84-86]$} \\
\hline $\begin{array}{l}\text { Agrobacterium-mediated } \\
\text { transformation }\end{array}$ & $\begin{array}{l}\text { C. reinhardtii } \\
\text { H. lacustris } \\
\text { Chlorella sp. } \\
\text { D. bardawil } \\
\text { Symbiodinium sp. } \\
\text { Nannochloropsis sp. } \\
\text { P. kessleri }\end{array}$ & $\begin{array}{l}\text { Low gene rearrangements; } \\
\text { low foreign transcript } \\
\text { silencing }\end{array}$ & $\begin{array}{l}\text { Labor-intensive; } \\
\text { no higher gene } \\
\text { expression reported }\end{array}$ & 10 & $10^{8}$ & 30 & {$[103,109]$} \\
\hline $\begin{array}{l}\text { Cell-Penetrating } \\
\text { Peptides }\end{array}$ & $\begin{array}{l}\text { Synechocystis sp. } \\
\text { S. elongatus } \\
\text { C. reinhardtii } \\
\text { C. vulgaris } \\
\text { P. tricornutum } \\
\text { D. salina } \\
\text { N. oleoabundans } \\
\text { S. dimorphus } \\
\text { Botrycoccus braunii }\end{array}$ & $\begin{array}{l}\text { High cargo stability; } \\
\text { internalized efficiently }\end{array}$ & $\begin{array}{c}\text { Requires cell wall } \\
\text { removal/deficiency; } \\
\text { optimized for mammalian } \\
\text { cells }\end{array}$ & $10^{4}$ & $10^{5}-10^{6}$ & $10-50$ & {$[129,130,132]$} \\
\hline $\begin{array}{c}\text { Metal-Organic } \\
\text { Frameworks (MOF) }\end{array}$ & C. reinhardtii & $\begin{array}{l}\text { High aqueous stability } \\
\text { pH-buffering capacity, } \\
\text { versatile }\end{array}$ & $\begin{array}{l}\text { Not yet optimized } \\
\text { requires cell wall } \\
\text { removal/deficiency }\end{array}$ & $10^{2}$ & $10^{6}$ & 0.7 & [152] \\
\hline
\end{tabular}




\section{Conclusions}

In addition to reviewing some classical transformation methods for both DNA and other molecules, this work has sought to bring attention to lesser-investigated yet emerging modes of transformation to the algal biotechnologist. Perhaps these alternative techniques can enhance transformation and transgene expression efficiency rates, or yield more controlled and targeted delivery to generate high-frequency tailored genome manipulations in both model and emerging algae hosts.

Funding: The authors would like to acknowledge King Abdullah University of Science and Technology (KAUST) for financial support.

Institutional Review Board Statement: Not applicable. No experimental data involving humans or animals were generated for the writing of this manuscript.

Informed Consent Statement: Not applicable. No experimental data involving humans were generated for the writing of this manuscript.

Data Availability Statement: All data presented in this manuscript are sourced from the respective publications cited herein. No other experimental data were generated for the writing of this manuscript. All illustrations have been produced using BioRender.com (accessed on 31 January 2021).

Acknowledgments: The authors thank Matthew Fechtmeyer and Gordon Wellman for critical reading of the manuscript.

Conflicts of Interest: The authors declare no conflict of interest.

\section{References}

1. Hallmann, A. Algal Transgenics and Biotechnology. Transgenic Plant J. 2007, 1, 81-98.

2. Fabris, M.; Abbriano, R.M.; Pernice, M.; Sutherland, D.L.; Commault, A.S.; Hall, C.C.; Labeeuw, L.; Mccauley, J.I.; Kuzhiuparambil, U.; Ray, P.; et al. Emerging Technologies in Algal Biotechnology: Toward the Establishment of a Sustainable, Algae-Based Bioeconomy. Front. Plant Sci. 2020, 11, 1-22. [CrossRef]

3. Nelson, D.R.; Hazzouri, K.M.; Lauersen, K.J.; Jaiswal, A.; Chaiboonchoe, A.; Mystikou, A.; Fu, W.; Daakour, S.; Dohai, B.; Alzahmi, A.; et al. Large-scale genome sequencing reveals the driving forces of viruses in microalgal evolution. Cell Host Microbe 2021, 29, 250-266.e8. [CrossRef]

4. Benedetti, M.; Vecchi, V.; Barera, S.; Dall'Osto, L. Biomass from microalgae: The potential of domestication towards sustainable biofactories. Microb. Cell Factories 2018, 17, 1-18. [CrossRef] [PubMed]

5. Khan, M.I.; Shin, J.H.; Kim, J.D. The promising future of microalgae: Current status, challenges, and optimization of a sustainable and renewable industry for biofuels, feed, and other products. Microb. Cell Factories 2018, 17, 1-21. [CrossRef]

6. Chen, H.; Li, T.; Wang, Q. Ten years of algal biofuel and bioproducts: Gains and pains. Planta 2019, 249, 195-219. [CrossRef] [PubMed]

7. Fu, W.; Chaiboonchoe, A.; Khraiwesh, B.; Nelson, D.R.; Al-Khairy, D.; Mystikou, A.; Alzahmi, A.; Salehi-Ashtiani, K. Algal cell factories: Approaches, applications, and potentials. Mar. Drugs 2016, 14, 225. [CrossRef]

8. Wannathong, T.; Waterhouse, J.C.; Young, R.E.B.; Economou, C.K.; Purton, S. New tools for chloroplast genetic engineering allow the synthesis of human growth hormone in the green alga Chlamydomonas reinhardtii. Appl. Microbiol. Biotechnol. 2016, 100, 5467-5477. [CrossRef]

9. Coll, J.M. Review. Methodologies for transferring DNA into eukaryotic microalgae. Spanish J. Agric. Res. 2006, 4, 316-330. [CrossRef]

10. Porter, R.D. Transformation in cyanobacteria. Crit. Rev. Microbiol. 1986, 13, 111-132. [CrossRef] [PubMed]

11. León, R.; Fernández, E.; Leon, R.; Fernandez, E. Nuclear transformation of eukaryotic microalgae: Historical overview, achievements and problems. In Advances in Experimental Medicine and Biology; Springer: New York, NY, USA, 2007; Volume 616, pp. 1-11, ISBN 9780387755311.

12. Klein, R.M.; Wolf, E.D.; Wu, R.; Sanford, J.C. High-velocity microprojectiles for delivering nucleic acids into living cells. 1987. Biotechnology 1992, 24, 384-386. [PubMed]

13. Kindle, K.L.; Schnell, R.A.; Fernandez, E.; Lefebvre, P.A. Stable nuclear transformation of Chlamydomonas using the Chlamydomonas gene for nitrate reductase. J. Cell Biol. 1989, 109, 2589-2601. [CrossRef]

14. Kindle, K.L. High-frequency nuclear transformation of Chlamydomonas reinhardtii. Proc. Natl. Acad. Sci. USA 1990, 87, 1228-1232. [CrossRef]

15. Sodeinde, O.A.; Kindle, K.L. Homologous recombination in the nuclear genome of Chlamydomonas reinhardtii. Proc. Natl. Acad. Sci. USA 1993, 90, 9199-9203. [CrossRef] [PubMed] 
16. Zhou, H.C.; Long, J.R.; Yaghi, O.M. Introduction to metal-organic frameworks. Chem. Rev. 2012, 112, 673-674. [CrossRef] [PubMed]

17. Silva, S.; Almeida, A.J.; Vale, N. Combination of cell-penetrating peptides with nanoparticles for therapeutic application: A review. Biomolecules 2019, 9, 22. [CrossRef] [PubMed]

18. Lanigan, T.M.; Kopera, H.C.; Saunders, T.L. Principles of Genetic Engineering. Genes 2020, 11, 291. [CrossRef] [PubMed]

19. Hawkins, R.L.; Nakamura, M. Expression of human growth hormone by the eukaryotic alga, Chlorella. Curr. Microbiol. 1999, 38, 335-341. [CrossRef]

20. Zienkiewicz, M.; Krupnik, T.; Drożak, A.; Kania, K. PEG-mediated, Stable, Nuclear and Chloroplast Transformation of Cyanidioschizon merolae. Bio-Protocol 2019, 9. [CrossRef] [PubMed]

21. Jin, E.S.; Polle, J.E.W.; Melis, A. Involvement of zeaxanthin and of the Cbr protein in the repair of photosystem II from photoinhibition in the green alga Dunaliella salina. Biochim. Biophys. Acta-Bioenerg. 2001, 1506, 244-259. [CrossRef]

22. Economou, C.; Wannathong, T.; Szaub, J.; Purton, S. A simple, low-cost method for chloroplast transformation of the green alga Chlamydomonas reinhardtii. Methods Mol. Biol. 2014, 1132, 401-411. [CrossRef]

23. Kindle, K.L.; Richards, K.L.; Stern, D.B. Engineering the chloroplast genome: Techniques and capabilities for chloroplast transformation in Chlamydomonas reinhardtii. Proc. Natl. Acad. Sci. USA 1991, 88, 1721-1725. [CrossRef] [PubMed]

24. Buchanan, M.J.; Snell, W.J. Biochemical studies on lysin, a cell wall degrading enzyme released during fertilization in Chlamydomonas. Exp. Cell Res. 1988. [CrossRef]

25. Zorin, B.; Hegemann, P.; Sizova, I. Nuclear-gene targeting by using single-stranded DNA avoids illegitimate DNA integration in Chlamydomonas reinhardtii. Eukaryot. Cell 2005, 4, 1264-1272. [CrossRef]

26. Rivera, A.L.; Magaña-Ortíz, D.; Gómez-Lim, M.; Fernández, F.; Loske, A.M. Physical methods for genetic transformation of fungi and yeast. Phys. Life Rev. 2014, 11, 184-203. [CrossRef]

27. Dunahay, T.G. Transformation of Chlamydomonas reinhardtii with silicon carbide whiskers. Biotechniques 1993, 15, 452-460. [PubMed]

28. Hiramatsu, S.; Ishihara, M.; Fujie, M.; Usami, S. Expression of a chitinase gene and lysis of the host cell wall during Chlorella virus CVK2 infection. Virology 1999, 260, 308-315. [CrossRef] [PubMed]

29. Sun, L.; Gurnon, J.R.; Adams, B.J.; Graves, M.V.; Van Etten, J.L. Characterization of a $\beta$-1,3-glucanase encoded by Chlorella virus PBCV-1. Virology 2000, 276, 27-36. [CrossRef]

30. Sugimoto, I.; Hiramatsu, S.; Murakami, D.; Fujie, M.; Usami, S.; Yamada, T. Algal-lytic activities encoded by Chlorella virus CVK2. Virology 2000, 277, 119-126. [CrossRef]

31. Kim, D.H.; Kim, Y.T.; Cho, J.J.; Bae, J.H.; Hur, S.B.; Hwang, I.; Choi, T.J. Stable integration and functional expression of flounder growth hormone gene in transformed microalga, Chlorella ellipsoidea. Mar. Biotechnol. 2002, 4, 63-73. [CrossRef]

32. Maruyama, M.; Horáková, I.; Honda, H.; Xing, X.H.; Shiragami, N.; Unno, H. Introduction of foreign DNA into Chlorella saccharophila by electroporation. Biotechnol. Tech. 1994, 8, 821-826. [CrossRef]

33. Jarvis, E.E.; Brown, L.M. Transient expression of firefly luciferase in protoplasts of the green alga Chlorella ellipsoidea. Curr. Genet. 1991, 19, 317-321. [CrossRef]

34. Shimogawara, K.; Fujiwara, S.; Grossman, A.; Usuda, H. High-efficiency transformation of Chlamydomonas reinhardtii by electroporation. Genetics 1998, 148, 1821-1828. [CrossRef]

35. Brown, L.E.; Sprecher, S.L.; Keller, L.R. Introduction of exogenous DNA into Chlamydomonas reinhardtii by electroporation. Mol. Cell. Biol. 1991, 11, 2328-2332. [CrossRef]

36. Weaver, J.C. Electroporation theory. Concepts and mechanisms. Methods Mol. Biol. 1995, 48, 3-28. [PubMed]

37. Ladygin, V.G. Efficient transformation of mutant cells of Chlamydomonas reinhardtii by electroporation. Process Biochem. 2004, 39, 1685-1691. [CrossRef]

38. Azencott, H.R.; Peter, G.F.; Prausnitz, M.R. Influence of the Cell Wall on Intracellular Delivery to Algal Cells by Electroporation and Sonication. Ultrasound Med. Biol. 2007, 33, 1805-1817. [CrossRef]

39. Tang, D.K.H.; Qiao, S.Y.; Wu, M. Insertion mutagenesis of Chlamydomonas reinhardtii by electroporation and heterologous DNA. Biochem. Mol. Biol. Int. 1995, 36, 1025-1035. [PubMed]

40. Chen, Y.; Hu, H. High efficiency transformation by electroporation of the freshwater alga Nannochloropsis limnetica. World J. Microbiol. Biotechnol. 2019, 35, 1-10. [CrossRef] [PubMed]

41. Zhang, C.; Hu, H. High-efficiency nuclear transformation of the diatom Phaeodactylum tricornutum by electroporation. Mar. Genom. 2014, 16, 63-66. [CrossRef]

42. Holmqvist, M.; Stensjö, K.; Oliveira, P.; Lindberg, P.; Lindblad, P. Characterization of the hupSL promoter activity in Nostoc punctiforme ATCC 29133. BMC Microbiol. 2009, 9. [CrossRef]

43. Thiel, T.; Poo, H. Transformation of a filamentous cyanobacterium by electroporation. J. Bacteriol. 1989, 171, 5743-5746. [CrossRef] [PubMed]

44. Jaeger, D.; Hübner, W.; Huser, T.; Mussgnug, J.H.; Kruse, O. Nuclear transformation and functional gene expression in the oleaginous microalga Monoraphidium neglectum. J. Biotechnol. 2017, 249, 10-15. [CrossRef]

45. Doron, L.; Segal, N.; Shapira, M. Transgene expression in microalgae-from tools to applications. Front. Plant Sci. $2016,7,505$. [CrossRef] [PubMed] 
46. Yamano, T.; Iguchi, H.; Fukuzawa, H. Rapid transformation of Chlamydomonas reinhardtii without cell-wall removal. J. Biosci. Bioeng. 2013, 115, 691-694. [CrossRef] [PubMed]

47. Wang, L.; Yang, L.; Wen, X.; Chen, Z.; Liang, Q.; Li, J.; Wang, W. Rapid and high efficiency transformation of Chlamydomonas reinhardtii by square-wave electroporation. Biosci. Rep. 2019, 39. [CrossRef]

48. Angstenberger, M.; De Signori, F.; Vecchi, V.; Dall'Osto, L.; Bassi, R. Cell Synchronization Enhances Nuclear Transformation and Genome Editing via Cas9 Enabling Homologous Recombination in Chlamydomonas reinhardtii. ACS Synth. Biol. 2020, 9, 2840-2850. [CrossRef] [PubMed]

49. Im, D.J.; Jeong, S.-N.; Yoo, B.S.; Kim, B.; Kim, D.-P.; Jeong, W.-J.; Kang, I.S. Digital Microfluidic Approach for Efficient Electroporation with High Productivity: Transgene Expression of Microalgae without Cell Wall Removal. Anal. Chem. 2015, 87, 6592-6599. [CrossRef]

50. Bodénès, P.; Wang, H.-Y.; Lee, T.-H.; Chen, H.-Y.; Wang, C.-Y. Microfluidic techniques for enhancing biofuel and biorefinery industry based on microalgae. Biotechnol. Biofuels 2019, 12, 33. [CrossRef] [PubMed]

51. Boynton, J.E.; Gillham, N.W.; Harris, E.H.; Hosler, J.P.; Johnson, A.M.; Jones, A.R.; Randolph-Anderson, B.L.; Robertson, D.; Klein, T.M.; Shark, K.B.; et al. Chloroplast transformation in Chlamydomonas with high velocity microprojectiles. Science 1988, 240, 1534-1538. [CrossRef]

52. Day, A.; Debuchy, R.; van Dillewijn, J.; Purton, S.; Rochaix, J.-D. Studies on the maintenance and expression of cloned DNA fragments in the nuclear genome of the green alga Chlamydomonas reinhardtii. Physiol. Plant. 1990, 78, 254-260. [CrossRef]

53. Remacle, C.; Cardol, P.; Coosemans, N.; Gaisne, M.; Bonnefoy, N. High-efficiency biolistic transformation of Chlamydomonas mitochondria can be used to insert mutations in complex I genes. Proc. Natl. Acad. Sci. USA 2006, 103, 4771-4776. [CrossRef]

54. Altpeter, F.; Baisakh, N.; Beachy, R.; Bock, R.; Capell, T.; Christou, P.; Daniell, H.; Datta, K.; Datta, S.; Dix, P.J.; et al. Particle bombardment and the genetic enhancement of crops: Myths and realities. Mol. Breed. 2005, 15, 305-327. [CrossRef]

55. Li, Z.; Bock, R. Replication of bacterial plasmids in the nucleus of the red alga Porphyridium purpureum. Nat. Commun. 2018, 9, 1-8. [CrossRef] [PubMed]

56. Ortiz-Matamoros, M.F.; Villanueva, M.A.; Islas-Flores, T. Genetic transformation of cell-walled plant and algae cells: Delivering DNA through the cell wall. Brief. Funct. Genom. 2018, 17, 26-33. [CrossRef] [PubMed]

57. Schiedlmeier, B.; Schmitt, R.; Müller, W.; Kirk, M.M.; Gruber, H.; Mages, W.; Kirk, D.L. Nuclear transformation of Volvox carteri. Proc. Natl. Acad. Sci. USA 1994, 91, 5080-5084. [CrossRef]

58. Feng, S.; Xue, L.; Liu, H.; Lu, P. Improvement of efficiency of genetic transformation for Dunaliella salina by glass beads method. Mol. Biol. Rep. 2009, 36, 1433-1439. [CrossRef] [PubMed]

59. Apt, K.E.; Grossman, A.R.; Kroth-Pancic, P.G. Stable nuclear transformation of the diatom Phaeodactylum tricornutum. Mol. Gen. Genet. MGG 1996, 252, 572-579. [CrossRef] [PubMed]

60. Randolph-Anderson, B.; Boynton, J.E.; Dawson, J.; Dunder, E.; Eskes, R.; Gillham, N.W.; Johnson, A.; Perlman, P.S.; Suttie, J.; Heiser, W.C. Sub-Micron Gold Particles are Superior to Larger Particles for Efficient Biolistic Transformation of Organelles and Some Cell Types. 1995. Available online: https://www.bio-rad.com/webroot/web/pdf/lsr/literature/Bulletin_2015.pdf (accessed on 31 January 2021).

61. Martin-Ortigosa, S.; Wang, K. Proteolistics: A biolistic method for intracellular delivery of proteins. Transgenic Res. 2014, 23, 743-756. [CrossRef] [PubMed]

62. Serif, M.; Dubois, G.; Finoux, A.L.; Teste, M.A.; Jallet, D.; Daboussi, F. One-step generation of multiple gene knock-outs in the diatom Phaeodactylum tricornutum by DNA-free genome editing. Nat. Commun. 2018, 9, 1-10. [CrossRef] [PubMed]

63. Mayfield, S.P.; Kindle, K.L. Stable nuclear transformation of Chlamydomonas reinhardtii by using a C. reinhardtii by using a C. reinhardtii gene as the selectable marker. Proc. Natl. Acad. Sci. USA 1990, 87, 2087-2091. [CrossRef] [PubMed]

64. Ramesh, V.M.; Bingham, S.E.; Webber, A.N. A simple method for chloroplast transformation in Chlamydomonas reinhardtii. Methods Mol. Biol. 2011, 684, 313-320. [CrossRef] [PubMed]

65. Stevens, S.E.; Porter, R.D. Heterospecific transformation among cyanobacteria. J. Bacteriol. 1986, 167, 1074-1076. [CrossRef]

66. Stucken, K.; Koch, R.; Dagan, T. Cyanobacterial defense mechanisms against foreign DNA transfer and their impact on genetic engineering. Biol. Res. 2013, 46, 373-382. [CrossRef] [PubMed]

67. Shestakov, S.V.; Khyen, N.T. Evidence for genetic transformation in blue-green alga Anacystis nidulans. MGG Mol. Gen. Genet. 1970, 107, 372-375. [CrossRef]

68. Grigorieva, G.; Shestakov, S. Transformation in the cyanobacterium Synechocystis sp. 6803. FEMS Microbiol. Lett. 1982, 13, 367-370. [CrossRef]

69. Onai, K.; Morishita, M.; Kaneko, T.; Tabata, S.; Ishiura, M. Natural transformation of the thermophilic cyanobacterium Thermosynechococcus elongatus BP-1: A simple and efficient method for gene transfer. Mol. Genet. Genom. 2004, 271, 50-59. [CrossRef] [PubMed]

70. Chen, I.; Dubnau, D. DNA uptake during bacterial transformation. Nat. Rev. Microbiol. 2004, 2, 241-249. [CrossRef]

71. Williams, J.G.K.; Szalay, A.A. Stable integration of foreign DNA into the chromosome of the cyanobacterium Synechococcus R2. Gene 1983, 24, 37-51. [CrossRef]

72. Yoshihara, S.; Geng, X.X.; Okamoto, S.; Yura, K.; Murata, T.; Go, M.; Ohmori, M.; Ikeuchi, M. Mutational analysis of genes involved in pilus structure, motility and transformation competency in the unicellular motile cyanobacterium Synechocystis sp. PCC 6803. Plant Cell Physiol. 2001, 42, 63-73. [CrossRef] 
73. Nakasugi, K.; Svenson, C.J.; Neilan, B.A. The competence gene, comF, from Synechocystis sp. strain PCC 6803 is involved in natural transformation, phototactic motility and piliation. Microbiology 2006, 152, 3623-3631. [CrossRef]

74. Wendt, K.E.; Pakrasi, H.B. Genomics approaches to deciphering natural transformation in cyanobacteria. Front. Microbiol. 2019, 10, 1-7. [CrossRef]

75. Proels, R. Stable Transformation of Cyanobacterium Synechocystis sp. Bio-Protocol 2014, 4. [CrossRef]

76. Nagarajan, A.; Winter, R.; Eaton-Rye, J.; Burnap, R. A synthetic DNA and fusion PCR approach to the ectopic expression of high levels of the D1 protein of photosystem II in Synechocystis sp. PCC 6803. J. Photochem. Photobiol. B Biol. 2011, 104, 212-219. [CrossRef] [PubMed]

77. Almeida, D.V.; Martens, S.B.B.; Lanes, C.F.C.; Marins, L.F. Improved genetic transformation of Synechococcus elongatus PCC 7942 using linear DNA fragments in association with a DNase inhibitor. Biotechnol. Res. Innov. 2017, 1, 123-128. [CrossRef]

78. Vioque, A. Transformation of cyanobacteria. Adv. Exp. Med. Biol. 2007, 616, 12-22. [PubMed]

79. Karas, B.J.; Diner, R.E.; Lefebvre, S.C.; McQuaid, J.; Phillips, A.P.R.; Noddings, C.M.; Brunson, J.K.; Valas, R.E.; Deerinck, T.J.; Jablanovic, J.; et al. Designer diatom episomes delivered by bacterial conjugation. Nat. Commun. 2015, 6, 1-10. [CrossRef]

80. Currier, T.C.; Wolk, C.P. Characteristics of Anabaena variabilis influencing plaque formation by cyanophage N-1. J. Bacteriol. 1979. [CrossRef]

81. Thiel, T.; Peter Wolk, C. Conjugal Transfer of Plasmids to Cyanobacteria. Methods Enzymol. 1987, 153, 232-243. [CrossRef] [PubMed]

82. Wolk, C.P.; Vonshak, A.; Kehoe, P.; Elhai, J. Construction of shuttle vectors capable of conjugative transfer from Escherichia coli to nitrogen-fixing filamentous cyanobacteria. Isotopenpraxis 1984, 20, 1561-1565. [CrossRef]

83. Brahamsha, B. A Genetic Manipulation System for Oceanic Cyanobacteria of the Genus Synechococcus. Appl. Environ. Microbiol. 1996, 62, 1747-1751. [CrossRef] [PubMed]

84. Tolonen, A.C.; Liszt, G.B.; Hess, W.R. Genetic Manipulation of Prochlorococcus Strain MIT9313: Green Fluorescent Protein Expression from an RSF1010 Plasmid and Tn5 Transposition. Appl. Environ. Microbiol. 2006, 72, 7607-7613. [CrossRef]

85. Marraccini, P.; Bulteau, S.; Cassier-Chauvat, C.; Mermet-Bouvier, P.; Chauvat, F. A conjugative plasmid vector for promoter analysis in several cyanobacteria of the genera Synechococcus and Synechocystis. Plant Mol. Biol. 1993, 23, 905-909. [CrossRef]

86. Tsinoremas, N.F.; Kutach, A.K.; Strayer, C.A.; Golden, S.S. Efficient gene transfer in Synechococcus sp. strains PCC 7942 and PCC 6301 by interspecies conjugation and chromosomal recombination. J. Bacteriol. 1994, 176, 6764-6768. [CrossRef] [PubMed]

87. Muñoz, C.F.; Sturme, M.H.J.; D'Adamo, S.; Weusthuis, R.A.; Wijffels, R.H. Stable transformation of the green algae Acutodesmus obliquus and Neochloris oleoabundans based on E. coli conjugation. Algal Res. 2019, 39, 101453. [CrossRef]

88. Fabris, M.; George, J.; Kuzhiumparambil, U.; Lawson, C.A.; Jaramillo-Madrid, A.C.; Abbriano, R.M.; Vickers, C.E.; Ralph, P. Extrachromosomal Genetic Engineering of the Marine Diatom Phaeodactylum tricornutum Enables the Heterologous Production of Monoterpenoids. ACS Synth. Biol. 2020. [CrossRef]

89. Dunahay, T.G.; Jarvis, E.E.; Roessler, P.G. Genetic Transformation of the Diatoms Cyclotella Cryptica and Navicula Saprophila. J. Phycol. 1995, 31, 1004-1012. [CrossRef]

90. Falciatore, A.; Casotti, R.; Leblanc, C.; Abrescia, C.; Bowler, C. Transformation of Nonselectable Reporter Genes in Marine Diatoms. Mar. Biotechnol. 1999, 1, 239-251. [CrossRef]

91. Miyagawa, A.; Okami, T.; Kira, N.; Yamaguchi, H.; Ohnishi, K.; Adachi, M. Research note: High efficiency transformation of the diatom Phaeodactylum tricornutum with a promoter from the diatom Cylindrotheca fusiformis. Phycol. Res. 2009, 57, 142-146. [CrossRef]

92. Diner, R.E.; Bielinski, V.A.; Dupont, C.L.; Allen, A.E.; Weyman, P.D. Refinement of the diatom episome maintenance sequence and improvement of conjugation-based DNA delivery methods. Front. Bioeng. Biotechnol. 2016, 4, 65. [CrossRef] [PubMed]

93. Cohen, M.F.; Wallis, J.G.; Campbell, E.L.; Meeks, J.C. Transposon mutagenesis of Nostoc sp. strain ATCC 29133, a filamentous cyanobacterium with multiple cellular differentiation alternatives. Microbiology 1994, 140, 3233-3240. [CrossRef]

94. Sharma, A.K.; Nymark, M.; Sparstad, T.; Bones, A.M.; Winge, P. Transgene-free genome editing in marine algae by bacterial conjugation-comparison with biolistic CRISPR/Cas9 transformation. Sci. Rep. 2018, 8, 1-11. [CrossRef]

95. Poliner, E.; Clark, E.; Cummings, C.; Benning, C.; Farre, E.M. A high-capacity gene stacking toolkit for the oleaginous microalga, Nannochloropsis oceanica CCMP1779. Algal Res. 2020, 45, 101664. [CrossRef]

96. Poliner, E.; Takeuchi, T.; Du, Z.Y.; Benning, C.; Farre, E.M. Non-transgenic marker-free gene disruption by an episomal CRISPR system in the oleaginous microalga, Nannochloropsis oceanica CCMP1779 Eric. Physiol. Behav. 2017, 176, 139-148. [CrossRef]

97. Tzfira, T.; Citovsky, V. Agrobacterium-mediated genetic transformation of plants: Biology and biotechnology. Curr. Opin. Biotechnol. 2006, 17, 147-154. [CrossRef] [PubMed]

98. Kunik, T. Genetic transformation of HeLa cells by Agrobacterium. Proc. Natl. Acad. Sci. USA 2001, 98, 1871-1876. [CrossRef] [PubMed]

99. Schell, J.; Van Montagu, M. The Ti-plasmid of Agrobacterium tumefaciens, a natural vector for the introduction of nif genes in plants? Basic Life Sci. 1977, 9, 159-179. [PubMed]

100. Zambryski, P.; Joos, H.; Genetello, C.; Leemans, J.; Van Montagu, M.; Schell, J. Ti plasmid vector for the introduction of DNA into plant cells without alteration of their normal regeneration capacity. EMBO J. 1983, 2, 2143-2150. [CrossRef]

101. Hamilton, C.M.; Frary, A.; Lewis, C.; Tanksley, S.D. Stable transfer of intact high molecular weight DNA into plant chromosomes. Proc. Natl. Acad. Sci. USA 1996, 93, 9975-9979. [CrossRef] [PubMed] 
102. Valvekens, D.; Montagu, M.V.; Lijsebettens, M.V. Agrobacterium tumefaciens-mediated transformation of Arabidopsis thaliana root explants by using kanamycin selection. Proc. Natl. Acad. Sci. USA 1988, 85, 5536-5540. [CrossRef] [PubMed]

103. Kumar, S.V.; Misquitta, R.W.; Reddy, V.S.; Rao, B.J.; Rajam, M.V. Genetic transformation of the green alga - Chlamydomonas reinhardtii by Agrobacterium tumefaciens. Plant Sci. 2004, 166, 731-738. [CrossRef]

104. Kathiresan, S.; Chandrashekar, A.; Ravishankar, G.A.; Sarada, R. Agrobacterium-mediated transformation in the green alga Haematococcus pluvialis (chlorophyceae, volvocales). J. Phycol. 2009, 45, 642-649. [CrossRef] [PubMed]

105. Cha, T.S.; Yee, W.; Aziz, A. Assessment of factors affecting Agrobacterium-mediated genetic transformation of the unicellular green alga, Chlorella vulgaris. World J. Microbiol. Biotechnol. 2012, 28, 1771-1779. [CrossRef]

106. Rathod, J.P.; Prakash, G.; Pandit, R.; Lali, A.M. Agrobacterium-mediated transformation of promising oil-bearing marine algae Parachlorella kessleri. Photosynth. Res. 2013, 118, 141-146. [CrossRef]

107. Anila, N.; Chandrashekar, A.; Ravishankar, G.A.; Sarada, R. Establishment of Agrobacterium tumefaciens -mediated genetic transformation in Dunaliella bardawil. Eur. J. Phycol. 2011, 46, 36-44. [CrossRef]

108. Pratheesh, P.T.; Vineetha, M.; Kurup, G.M. An efficient protocol for the Agrobacterium-mediated genetic transformation of microalga Chlamydomonas reinhardtii. Mol. Biotechnol. 2014, 56, 507-515. [CrossRef]

109. Mini, P.; Demurtas, O.C.; Valentini, S.; Pallara, P.; Aprea, G.; Ferrante, P.; Giuliano, G. Agrobacterium-mediated and electroporationmediated transformation of Chlamydomonas reinhardtii: A comparative study. BMC Biotechnol. 2018, 18, 11. [CrossRef] [PubMed]

110. Prasad, B.; Lein, W.; Thiyam, G.; Lindenberger, C.P.; Buchholz, R.; Vadakedath, N. Stable nuclear transformation of rhodophyte species Porphyridium purpureum: Advanced molecular tools and an optimized method. Photosynth. Res. 2019, 140, 173-188. [CrossRef]

111. Michielse, C.B.; Hooykaas, P.J.J.; van den Hondel, C.A.M.J.J.; Ram, A.F.J. Agrobacterium-mediated transformation as a tool for functional genomics in fungi. Curr. Genet. 2005, 48, 1-17. [CrossRef]

112. Lauersen, K.J. Eukaryotic microalgae as hosts for light-driven heterologous isoprenoid production. Planta 2019, 249, 155-180. [CrossRef]

113. Zhang, R.; Patena, W.; Armbruster, U.; Gang, S.S.; Blum, S.R.; Jonikas, M.C. High-throughput genotyping of green algal mutants reveals random distribution of mutagenic insertion sites and endonucleolytic cleavage of transforming DNA. Plant Cell 2014, 26, 1398-1409. [CrossRef]

114. Lin, H.; Cliften, P.F.; Dutcher, S.K. MAPINS, a highly efficient detection method that identifies insertional mutations and complex DNA rearrangements. Plant Physiol. 2018, 178, 1436-1447. [CrossRef] [PubMed]

115. Rádis-Baptista, G.; Campelo, I.S.; Morlighem, J.É.R.L.; Melo, L.M.; Freitas, V.J.F. Cell-penetrating peptides (CPPs): From delivery of nucleic acids and antigens to transduction of engineered nucleases for application in transgenesis. J. Biotechnol. 2017, 252, 15-26. [CrossRef]

116. Lehto, T.; Ezzat, K.; Wood, M.J.A.; EL Andaloussi, S. Peptides for nucleic acid delivery. Adv. Drug Deliv. Rev. 2016, 106, 172-182. [CrossRef]

117. Margus, H.; Padari, K.; Pooga, M. Cell-penetrating peptides as versatile vehicles for oligonucleotide delivery. Mol. Ther. 2012, 20, 525-533. [CrossRef]

118. Mishra, V.K.; Anantharamaiah, G.M.; Segrest, J.P.; Palgunachari, M.N.; Chaddha, M.; Sham, S.W.S.; Krishna, N.R. Association of a Model Class A (Apolipoprotein) Amphipathic $\alpha$ Helical Peptide with Lipid. J. Biol. Chem. 2006, 281, 6511-6519. [CrossRef] [PubMed]

119. Fernández-Carneado, J.; Kogan, M.J.; Pujals, S.; Giralt, E. Amphipathic Peptides and Drug Delivery. Proc. Biopolym. Pept. Sci. Sect. 2004, 76, 196-203. [CrossRef] [PubMed]

120. Morris, M.C.; Vidal, P.; Chaloin, L.; Heitz, F.; Divita, G. A new peptide vector for efficient delivery of oligonucleotides into mammalian cells. Nucleic Acids Res. 1997, 25, 2730-2736. [CrossRef] [PubMed]

121. Chugh, A.; Eudes, F. Cellular uptake of cell-penetrating peptides pVEC and transportan in plants. J. Pept. Sci. 2008, 14, 477-481. [CrossRef] [PubMed]

122. Oehlke, J.; Scheller, A.; Wiesner, B.; Krause, E.; Beyermann, M.; Klauschenz, E.; Melzig, M.; Bienert, M. Cellular uptake of an $\alpha$-helical amphipathic model peptide with the potential to deliver polar compounds into the cell interior non-endocytically. Biochim. Biophys. Acta-Biomembr. 1998. [CrossRef]

123. Gräslund, A.; Madani, F.; Lindberg, S.; Langel, Ü.; Futaki, S. Mechanisms of cellular uptake of cell-penetrating peptides. J. Biophys. 2011, 2011, 414729.

124. Pooga, M.; Langel, Ü. Classes of cell-penetrating peptides. In Cell-Penetrating Peptides: Methods and Protocols; Springer: New York, NY, USA, 2015; pp. 3-28, ISBN 9781493928064.

125. Fuselier, T.; Wimley, W.C. Spontaneous Membrane Translocating Peptides: The Role of Leucine-Arginine Consensus Motifs. Biophys. J. 2017, 113, 835-846. [CrossRef] [PubMed]

126. Vivès, E.; Brodin, P.; Lebleu, B. A truncated HIV-1 Tat protein basic domain rapidly translocates through the plasma membrane and accumulates in the cell nucleus. J. Biol. Chem. 1997, 272, 16010-16017. [CrossRef] [PubMed]

127. Derossi, D.; Joliot, A.H.; Chassaing, G.; Prochiantz, A. The third helix of the Antennapedia homeodomain translocates through biological membranes. J. Biol. Chem. 1994, 269, 10444-10450. [CrossRef]

128. Rojas, M.; Donahue, J.P.; Tan, Z.; Lin, Y.Z. Genetic engineering of proteins with cell membrane permeability. Nat. Biotechnol. 1998, 16, 370-375. [CrossRef] 
129. Liu, B.R.; Huang, Y.W.; Lee, H.J. Mechanistic studies of intracellular delivery of proteins by cell-penetrating peptides in cyanobacteria. BMC Microbiol. 2013, 13, 57. [CrossRef]

130. Wei, Y.; Niu, J.; Huan, L.; Huang, A.; He, L.; Wang, G. Cell penetrating peptide can transport dsRNA into microalgae with thin cell walls. Algal Res. 2015, 8, 135-139. [CrossRef]

131. Frankel, A.D.; Pabo, C.O. Cellular uptake of the tat protein from human immunodeficiency virus. Cell 1988, 55, 1189-1193. [CrossRef]

132. Hyman, J.M.; Geihe, E.I.; Trantow, B.M.; Parvin, B.; Wender, P.A. A molecular method for the delivery of small molecules and proteins across the cell wall of algae using molecular transporters. Proc. Natl. Acad. Sci. USA 2012, 109, 13225-13230. [CrossRef] [PubMed]

133. Gadamchetty, P.; Mullapudi, P.L.V.; Sanagala, R.; Markandan, M.; Polumetla, A.K. Genetic transformation of Chlorella vulgaris mediated by HIV-TAT peptide. 3 Biotech 2019, 9, 139. [CrossRef] [PubMed]

134. Suresh, A.; Kim, Y.C. Translocation of cell penetrating peptides on Chlamydomonas reinhardtii. Biotechnol. Bioeng. 2013, 110, 2795-2801. [CrossRef]

135. Holm, T.; Netzereab, S.; Hansen, M.; Langel, Ü.; Hällbrink, M. Uptake of cell-penetrating peptides in yeasts. FEBS Lett. 2005, 579, 5217-5222. [CrossRef] [PubMed]

136. Joliot, A.; Pernelle, C.; Deagostini-Bazin, H.; Prochiantz, A. Antennapedia homeobox peptide regulates neural morphogenesis. Proc. Natl. Acad. Sci. USA 1991, 88, 1864-1868. [CrossRef]

137. Kang, S.; Jeon, S.; Kim, S.; Chang, Y.K.; Kim, Y.C. Development of a pVEC peptide-based ribonucleoprotein (RNP) delivery system for genome editing using CRISPR/Cas9 in Chlamydomonas reinhardtii. Sci. Rep. 2020, 10, 1-11. [CrossRef] [PubMed]

138. Kang, S.; Suresh, A.; Kim, Y.C. A highly efficient cell penetrating peptide pVEC-mediated protein delivery system into microalgae. Algal Res. 2017, 24, 360-367. [CrossRef]

139. Boussif, O.; LezoualC'H, F.; Zanta, M.A.; Mergny, M.D.; Scherman, D.; Demeneix, B.; Behr, J.P. A versatile vector for gene and oligonucleotide transfer into cells in culture and in vivo: Polyethylenimine. Proc. Natl. Acad. Sci. USA 1995, 92, 7297-7301. [CrossRef]

140. Haensler, J.; Szoka, F.C. Polyamidoamine Cascade Polymers Mediate Efficient Transfection of Cells in Culture. Bioconjug. Chem. 1993, 4, 372-379. [CrossRef] [PubMed]

141. Benjaminsen, R.V.; Mattebjerg, M.A.; Henriksen, J.R.; Moghimi, S.M.; Andresen, T.L. The possible "proton sponge" effect of polyethylenimine (PEI) does not include change in lysosomal pH. Mol. Ther. 2013, 21, 149-157. [CrossRef]

142. Pack, D.W.; Hoffman, A.S.; Pun, S.; Stayton, P.S. Design and development of polymers for gene delivery. Nat. Rev. Drug Discov. 2005, 4, 581-593. [CrossRef] [PubMed]

143. Thomas, M.; Klibanov, A.M. Enhancing polyethylenimine's delivery of plasmid DNA into mammalian cells. Proc. Natl. Acad. Sci. USA 2002, 99, 14640-14645. [CrossRef] [PubMed]

144. Forrest, M.L.; Meister, G.E.; Koerber, J.T.; Pack, D.W. Partial Acetylation of Polyethylenimine Enhances In Vitro Gene Delivery. Pharm. Res. 2004, 21, 365-371. [CrossRef] [PubMed]

145. Carboni, V.; Maaliki, C.; Alyami, M.; Alsaiari, S.; Khashab, N. Synthetic Vehicles for Encapsulation and Delivery of CRISPR/Cas9 Gene Editing Machinery. Adv. Ther. 2019, 2, 1800085. [CrossRef]

146. Furukawa, H.; Cordova, K.E.; O'Keeffe, M.; Yaghi, O.M. The chemistry and applications of metal-organic frameworks. Science 2013, 341. [CrossRef]

147. Alsaiari, S.K.; Patil, S.; Alyami, M.; Alamoudi, K.O.; Aleisa, F.A.; Merzaban, J.S.; Li, M.; Khashab, N.M. Endosomal Escape and Delivery of CRISPR/Cas9 Genome Editing Machinery Enabled by Nanoscale Zeolitic Imidazolate Framework. J. Am. Chem. Soc. 2018, 140, 143-146. [CrossRef]

148. Alyami, M.Z.; Alsaiari, S.K.; Li, Y.; Qutub, S.S.; Aleisa, F.A.; Sougrat, R.; Merzaban, J.S.; Khashab, N.M. Cell-Type-Specific CRISPR/Cas9 Delivery by Biomimetic Metal Organic Frameworks. J. Am. Chem. Soc. 2020, 142, 1715-1720. [CrossRef]

149. Patil, A.J.; Muthusamy, E.; Mann, S. Synthesis and Self-Assembly of Organoclay-Wrapped Biomolecules. Angezw. Chemie Int. Ed. 2004, 43, 4928-4933. [CrossRef] [PubMed]

150. Patil, A.J.; Li, M.; Dujardin, E.; Mann, S. Novel bioinorganic nanostructures based on mesolamellar intercalation or single-molecule wrapping of DNA using organoclay building blocks. Nano Lett. 2007, 7, 2660-2665. [CrossRef] [PubMed]

151. Mann, S. Self-assembly and transformation of hybrid nano-objects and nanostructures under equilibrium and non-equilibrium conditions. Nat. Mater. 2009, 8, 781-792. [CrossRef] [PubMed]

152. Kim, S.; Lee, Y.-C.; Cho, D.-H.; Lee, H.U.; Huh, Y.S.; Kim, G.-J.; Kim, H.-S. A Simple and Non-Invasive Method for Nuclear Transformation of Intact-walled Chlamydomonas reinhardtii. PLoS ONE 2014, 9, e101018. [CrossRef] [PubMed]

153. Mann, S.; Burkett, S.L.; Davis, S.A.; Fowler, C.E.; Mendelson, N.H.; Sims, S.D.; Walsh, D.; Whilton, N.T. Sol-Gel Synthesis of Organized Matter. Chem. Mater. 1997, 9, 2300-2310. [CrossRef]

154. Han, H.K.; Lee, Y.C.; Lee, M.Y.; Patil, A.J.; Shin, H.J. Magnesium and calcium organophyllosilicates: Synthesis and in vitro cytotoxicity study. ACS Appl. Mater. Interfaces 2011, 3, 2564-2572. [CrossRef]

155. Kim, J.; Grate, J.W. Single-Enzyme Nanoparticles Armored by a Nanometer-Scale Organic/Inorganic Network. Nano Lett. 2003, 3, 1219-1222. [CrossRef]

156. Ichinose, I.; Hashimoto, Y.; Kunitake, T. Wrapping of Bio-macromolecules (Dextran, Amylopectin, and Horse Heart Cytochrome c) with Ultrathin Silicate Layer. Chem. Lett. 2004, 33, 656-657. [CrossRef] 
157. Numata, M.; Li, C.; Bae, A.H.; Kaneko, K.; Sakurai, K.; Shinkai, S. B-1,3-Glucan Polysaccharide Can Act As a One-Dimensional Host To Create Novel Silica Nanofiber Structures. Chem. Commun. 2005, 4655-4657. [CrossRef] [PubMed]

158. Li, H.; Eddaoudi, M.; O'Keeffe, M.; Yaghi, O.M. Design and synthesis of an exceptionally stable and highly porous metal- organic framework. Nature 1999, 402, 276-279. [CrossRef]

159. Phan, A.; Doonan, C.J.; Uribe-Romo, F.J.; Knobler, C.B.; Okeeffe, M.; Yaghi, O.M. Synthesis, structure, and carbon dioxide capture properties of zeolitic imidazolate frameworks. Acc. Chem. Res. 2010, 43, 58-67. [CrossRef] [PubMed]

160. Venna, S.R.; Jasinski, J.B.; Carreon, M.A. Structural evolution of zeolitic imidazolate framework-8. J. Am. Chem. Soc. 2010, 132, 18030-18033. [CrossRef]

161. Liang, K.; Ricco, R.; Doherty, C.M.; Styles, M.J.; Bell, S.; Kirby, N.; Mudie, S.; Haylock, D.; Hill, A.J.; Doonan, C.J.; et al. Biomimetic mineralization of metal-organic frameworks as protective coatings for biomacromolecules. Nat. Commun. 2015, 6. [CrossRef]

162. Shieh, F.K.; Wang, S.C.; Yen, C.I.; Wu, C.C.; Dutta, S.; Chou, L.Y.; Morabito, J.V.; Hu, P.; Hsu, M.H.; Wu, K.C.W.; et al. Imparting Functionality to Biocatalysts via Embedding Enzymes into Nanoporous Materials by a de Novo Approach: Size-Selective Sheltering of Catalase in Metal-Organic Framework Microcrystals. J. Am. Chem. Soc. 2015, 137, 4276-4279. [CrossRef] [PubMed]

163. Parker, A.L.; Newman, C.; Briggs, S.; Seymour, L.; Sheridan, P.J. Nonviral gene delivery: Techniques and implications for molecular medicine. Expert Rev. Mol. Med. 2003, 5. [CrossRef]

164. Balazs, D.A.; Godbey, W.T. Liposomes for Use in Gene Delivery. J. Drug Deliv. 2011, 2011, 1-12. [CrossRef] [PubMed]

165. Hug, P.; Sleight, R.G. Liposomes for the transformation of eukaryotic cells. BBA-Mol. Basis Dis. 1991, 1097, 1-17. [CrossRef]

166. Gad, A.E.; Rosenberg, N.; Altman, A. Liposome-mediated gene delivery into plant cells. Physiol. Plant. 1990, 79, $177-183$. [CrossRef]

167. Thierry, A.R.; Rabinovich, P.; Peng, B.; Mahan, L.C.; Bryant, J.L.; Gallo, R.C. Characterization of liposome-mediated gene delivery: Expression, stability and pharmacokinetics of plasmid DNA. Gene Ther. 1997, 4, 226-237. [CrossRef] [PubMed]

168. Akbarzadeh, A.; Rezaei-Sadabady, R.; Davaran, S.; Joo, S.W.; Zarghami, N.; Hanifehpour, Y.; Samiei, M.; Kouhi, M.; Nejati-Koshki, K. Liposome: Classification, preparation, and applications. Nanoscale Res. Lett. 2013, 8, 8-18. [CrossRef] [PubMed]

169. Jesorka, A.; Orwar, O. Liposomes: Technologies and Analytical Applications. Annu. Rev. Anal. Chem. 2008, 1, 801-832. [CrossRef]

170. Ohta, K.; Ichihashi, N. Liposome fragment-mediated introduction of multiple plasmids into Bacillus subtilis. Biochem. Biophys. Reports 2019, 18, 100646. [CrossRef] [PubMed]

171. Yachi, K.; Harashima, H.; Kikuchi, H.; Sudo, R.; Yamauchi, H.; Ebihara, K.; Matsuo, H.; Funato, K.; Kiwada, H. Biopharmaceutical evaluation of the liposomes prepared by rehydration of freeze-dried empty liposomes (FDELs) with an aqueous solution of a drug. Biopharm. Drug Dispos. 1996, 17, 589-605. [CrossRef]

172. Mannino, R.J.; Gould-Fogerite, S. Liposome mediated gene transfer. Biotechniques 1988, 6, 682-690. [CrossRef] 